\title{
FORMULATION AND DEVELOPMENT OF LORNOXICAM BILAYER TABLETS
}

\author{
D R Nagesh ${ }^{1}$, Rakesh Kumar Jat ${ }^{1}$, Syed Mansoor Ahmed ${ }^{2}$ \\ ${ }^{1}$ Institute of Pharmacy, Shri Jagdishprasad Jhabarmal Tibrewala University, Jhunjhunu, India \\ ${ }^{2}$ Sri Siddaganga college of Pharmacy, B.H. Road, Tumkur 572102 India
}

\section{ABSTRACT}

Point of present examination work was attempted to figure bilayer tablets of lornoxicam through its joining of oral measurements frame that can release lornoxicam promptly in addition maintained sustained release of lornoxicam for 24 hrs to improve oral bioavailability of lornoxicam. Primary target of this work was plan of bilayer tablets utilizing superdisintegrant Kyron 314 for smart discharge layer Polyox 303 for supporting discharge layer made out of two unique classes of medications by utilizing straight forward simple to-scale-up definition system. The in vitro dissolution study of the prepared bilayer tablets showed a controlled release of active drugs over a period of 24 hours

Key Words: Bilayer Tablets, lornoxicam, Superdisintegrant, sustained release

Article Info: Received 13 Oct, 2017; Review Completed 26 Nov, 2017; Accepted 28 Nov, 2017; Available online 28 Nov, 2017

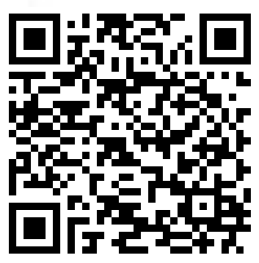

Cite this article as: Nagesh DR, Jat RK, Ahmed SM, Formulation and development of lornoxicam bilayer tablets, Journal of Drug Delivery and Therapeutics. 2017; 7(6):132-138

DOI: http://dx.doi.org/10.22270/jddt.v7i6.1534

*Address for Correspondence: D R Nagesh, Institute of Pharmacy, Shri Jagdishprasad Jhabarmal Tibrewala University, Jhunjhunu, India. E-mail: nageshdr29@gmail.com

\section{INTRODUCTION}

Oral route is the most commonly employed route of drug administration. Although different Route of administration are used for the delivery of drugs, oral route remain the preferred mode. The popularity of the oral route is attributed patient acceptance, ease of administration, accurate dosing, cost effective manufacturing method and generally improved shelf-life of the product. Even for sustained release systems the oral route of administration has been investigated the most, because of flexibility in dosage forms design that the oral route offers. With many drugs, the basic goal of therapy is to achieve a steady-state blood level or tissue level that is therapeutically effective and non-toxic for an extended period of time. $1,2,3$

Bi-layer tablet concept has long been utilized to develop sustained released formulation. Such tablet has a fast releasing layer and may contain one (bi-layer), to sustain the drug release. The pharmacokinetic advantage relies on the criterion that, drug release from the fast releasing layer leads to a sudden rise in the blood concentration. However the blood level is maintained at steady state as the release from sustaining layer. ${ }^{4,5,6}$

Lornoxicam, a congener of tenoxicam, is a novel NSAID belonging to the oxicam group5 with extremely potent anti-inflammatory and analgesic activities ${ }^{7,8}$. It is widely used for the symptomatic treatment of pain and inflammation in patients with rheumatoid arthritis and osteoarthritis ${ }^{9}$

Bi-layer tablet is sensible for dynamic passage of two medicines in mix, separate two contradicting substances other than for kept up discharge tablet in which one layer is energetic discharge as beginning estimations second layer is reinforce estimation. This bilayer approach is a convenient method. Hence it makes possible to formulate sustained release preparations with the immediate release quantity in one layer and the slow release portion will disintegrate rapidly after ingestion thus providing the Initial dose of medication for immediate onset of action, where as the another layer in 
the matrix layer remain intact during most of the time of its passage through the intestine, While dissolving slowly (sustained manner) from its exposed faces in this passage, which helps to maintain the blood level initially reached.

\section{METHODOLOGY}

Preformulation study ${ }^{10}$ :

\section{Organoleptic Characteristics of Lornoxicam}

Physical examine was done to check Organoleptic Characteristics of LORNOXICAM like odor.

\section{Solubility study of Lornoxicam}

This study done using different solvents like water, ethanol, methanol, DCM, DMSO.

Preparation of Calibration Curve for Lornoxicam:

$100 \mathrm{mg}$ of pure lornoxicam was dissolved in $100 \mathrm{ml}$ of $\mathrm{pH} 6.8$ phosphate buffer. $1 \mathrm{ml}$ of this solution was pipette out in separate $10 \mathrm{ml}$ volumetric flask diluted suitable media subjected to UV scanning in range 200$400 \mathrm{~nm}$ using double beam UV-visible spectrophotometer.

Preparation of 0.1N HCL: It was prepared by diluting $8.33 \mathrm{ml}$ of concentrated HCL with $1000 \mathrm{ml}$ with distilled water.

Preparation of Phosphate Buffer $6.8 \mathrm{pH}: 2.38 \mathrm{gm}$ of disodium hydrogen phosphate, $0.19 \mathrm{gm}$ of potassium dihydrogen phosphate8gm of $\mathrm{Nacl}$ were dissolved in water volume up to $1000 \mathrm{ml}$. Adjust $\mathrm{pH}$.

Preparation of Standard solution $(100 \mu \mathrm{g} / \mathrm{ml}): 100 \mathrm{mg}$ of lornoxicam was dissolved in ethanol make up $100 \mathrm{ml}$ 6.8 phosphate buffer. $1 \mathrm{ml}$ of solution was pipette out in separate volumetric flask diluted it up to $10 \mathrm{ml}$ with phosphate buffer 6.8 to produce $100 \mu \mathrm{g} / \mathrm{ml}$.

From standard solution of lornoxicam, aliquots of 0.1, $0.2, \quad 0.3,0.4,0.5, \quad 0.6, \quad 0.70 .8$ were withdrawn subsequently diluted up to $10 \mathrm{ml}$ with phosphate buffer of $\mathrm{pH} 6.8$ to obtain series of dilutions containing 10, 20, $30,40,50,60,70,80 \mu \mathrm{g} / \mathrm{ml}$ solution. Absorbance of these solutions was measured UV-Visible Spectrophotometer at $260 \mathrm{~nm}$ using phosphate buffer of pH 6.8 as blank.

Drug-excipients compatibility Studies by FTIR Spectroscopy ${ }^{11}$

IR spectroscopy will conducted using FTIR Spectrophotometer spectrum was recorded in wavelength region of $400-4000 \mathrm{~cm}^{-1}$. Procedure consisted of dispersing sample drug alone mixture of drug polymer in $\mathrm{KBr}$ compressing into discs by applying pressure of $5 \mathrm{t}$ for $5 \mathrm{~min}$ in hydraulic press. Pellet was placed in light path spectrum was recorded.
Preparation of Lornoxicam Bilayer Tablets:

Method of preparation of Sustained Release Layer ${ }^{12}$

Lornoxicam sustain release layer had been formulated by utilizing direct compression procedure. Weighed quantities of desired weighed of solid medicament other excipients like MCC, Retardant polymer were mixed properly shifted from sieve no 40 . Before compression add talc, magnesium stearate mixed it well. Prepared powder blended than punched by using single punch tablet compression machine.

Table 1: Composition of Lornoxicam Sustained Release Layer Tablet (1 TABLET)

\begin{tabular}{|c|c|}
\hline Tablet composition & Weight $(\mathbf{m g})$ \\
\hline Lornoxicam & 8 \\
\hline Retardant material & $25-75 \%$ \\
\hline MCC & 37 \\
\hline Talc & 3 \\
\hline Magnesium Stearate & 2 \\
\hline Total & 150 \\
\hline
\end{tabular}

\section{Method of Preparation of Immediate release Layer}

Lornoxicam Orodispersible layer were prepared by using direct compression method. Desired quantities already weighed material and other excipients like MCC, superdisintegrant, aspartame, agent were mixed properly shifted from sieve no 40 . Before compression add talc, magnesium stearate mixed it well. Prepared powder blended than punched by using single punch tablet compression machine.

Drug Content Uniformity ${ }^{12,13}$

Ten Tablets were finely powdered and an amount equivalent to $40 \mathrm{mg}$ of Lornoxicam was accurately weighed and transferred to a $100 \mathrm{ml}$ volumetric flask. Then $70 \mathrm{ml}$ methanol was added. The flask was shaken for 10 minutes. Finally, the volume was made up to the mark with methanol. The mixture was then filtered and 1 $\mathrm{ml}$ of the filtrate was suitably diluted with methanol to obtain a solution containing about $40 \mu \mathrm{g} \mathrm{ml}{ }^{-1}$ of Lornoxicam and analyzed for Lornoxicam content at 260 $\mathrm{nm}$ using a double beam UV/Visible and methanol as a blank.

In-vitro Drug Release Study of Ketoprofen Bilayer Tablets:

Release of Lornoxicam was determined using a USP, six stage dissolution rate test apparatus- I at $50 \mathrm{rpm}$. The dissolution was studied using $900 \mathrm{~mL}$ of simulated intestinal fluid (without enzyme $\mathrm{pH}$ 6.8). The temperature was maintained at $37 \pm 0.5^{\circ} \mathrm{C}$. The sample $(5 \mathrm{ml})$ was withdrawn at different time intervals i.e. $1,2,3,4,5,6,7,8,9,10,11,12 \mathrm{hrs}$ filter through whatman filter paper and replaced by an equal volume of dissolution medium sample were suitably diluted and analyzed for Lornoxicam content at $376 \mathrm{~nm}$. 


\section{RESULT AND DISCUSSION}

Preformulation Study for Lornoxicam:

Preformulation parameters, for example, Organoleptic trademark study, Melting Point Determination, dissolvability study Wavelength $(\lambda \max )$ Determination, Calibration bend, Identification of Drug by Lornoxicam, DSC study FT-IR study was completed. This incorporates different Preformulation thinks about for present examination work result talks about underneath each parameter.

\section{Organoleptic Characteristics of Lornoxicam}

Table 1: Organoleptic Characteristics of Lornoxicam

\begin{tabular}{|c|c|}
\hline PARAMETER & OBSERVED RESULT \\
\hline Color & Yellow White powder \\
\hline Odor & slightly unctuous with faint \\
\hline Appearance & Yellow crystalline powder \\
\hline
\end{tabular}

Shade of Lornoxicam was imagined yellow with marginally unctuous or with weak trademark smell having yellow crystalline powder appearance as appeared in Table 13.

Preparation of Calibration Curve for Lornoxicam

Absorbance was examined between 200 to $400 \mathrm{~nm}$ and $\lambda \max$ was found $376 \mathrm{~nm}$.

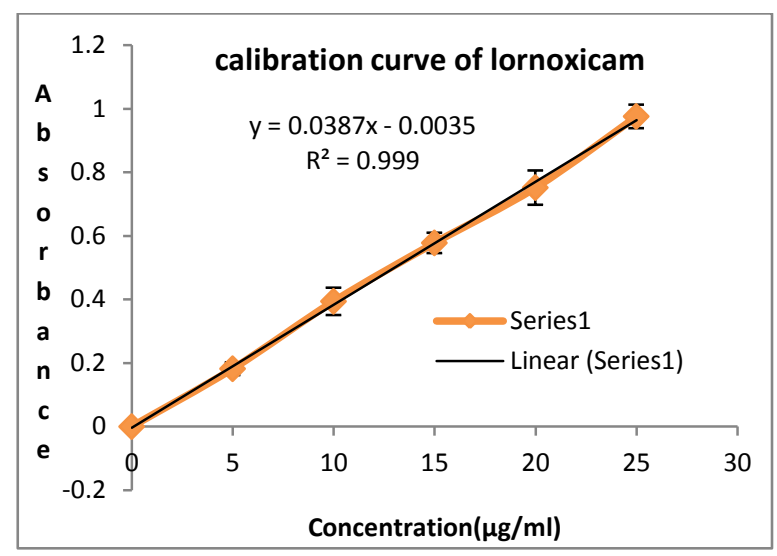

Figure 1: Calibration curve of Lornoxicam in phosphate buffer

Adjustment bend for Lornoxicam was gotten by utilizing $0-25 \mu \mathrm{g} / \mathrm{mL}$ arrangement of Lornoxicam in Phosphate cradle $\mathrm{pH}$ 7.4. Absorbance was measured at $376 \mathrm{~nm}$. Adjustment bend for Lornoxicam was appeared in figure 5.3. Absorbance acquired for given focuses was appeared in Table 18. Alignment bend indicates relapse condition $\mathrm{Y}=0.0387 \times \mathrm{x} 2$ value 0.999 . Result uncovered that medication focus between $0-25 \mu \mathrm{g} / \mathrm{mL}$ takes after Beer Lambert's law as relapse coefficient was 0.999 .

\section{Solubility study of Lornoxicam}

Table 3: Solubility of Lornoxicam

\begin{tabular}{|c|c|c|c|}
\hline S. $\mathbf{N}$. & Solvents & $\begin{array}{c}\text { Solubility }(\mathbf{m g} / \mathbf{m L}) \\
(\text { Mean } \mathbf{\text { S.D. }})(\mathbf{n}=\mathbf{3})\end{array}$ & Interpretation \\
\hline 1. & Water & $\mathbf{0 . 0 2 2} \pm \mathbf{0 . 0 2 1}$ & Very Slightly soluble \\
\hline 2. & Ethanol & $\mathbf{1 . 1 3} \pm \mathbf{0 . 9 4}$ & Slightly soluble \\
\hline 3. & Methanol & $\mathbf{4 . 3 3} \pm \mathbf{0 . 5 6}$ & Partially soluble \\
\hline 4. & DCM & $\mathbf{5 . 9 4} \pm \mathbf{0 . 9 8}$ & Partially soluble \\
\hline 5. & Methanol: DCM & $\mathbf{9 . 4 5} \pm \mathbf{0 . 3 2}$ & Freely soluble \\
\hline 6. & DMSO & $\mathbf{3 . 7 2} \pm \mathbf{0 . 0 9}$ & Slightly soluble \\
\hline
\end{tabular}

Identification of Lornoxicam by FT-IR Spectroscopy

Potassium bromide IR circle was readied utilizing 1 mg of Lornoxicam on Hydraulic Pellet press checked in locale of 4000-400 cm-1. Gotten IR Spectrum was contrasted reference range of Lornoxicam.

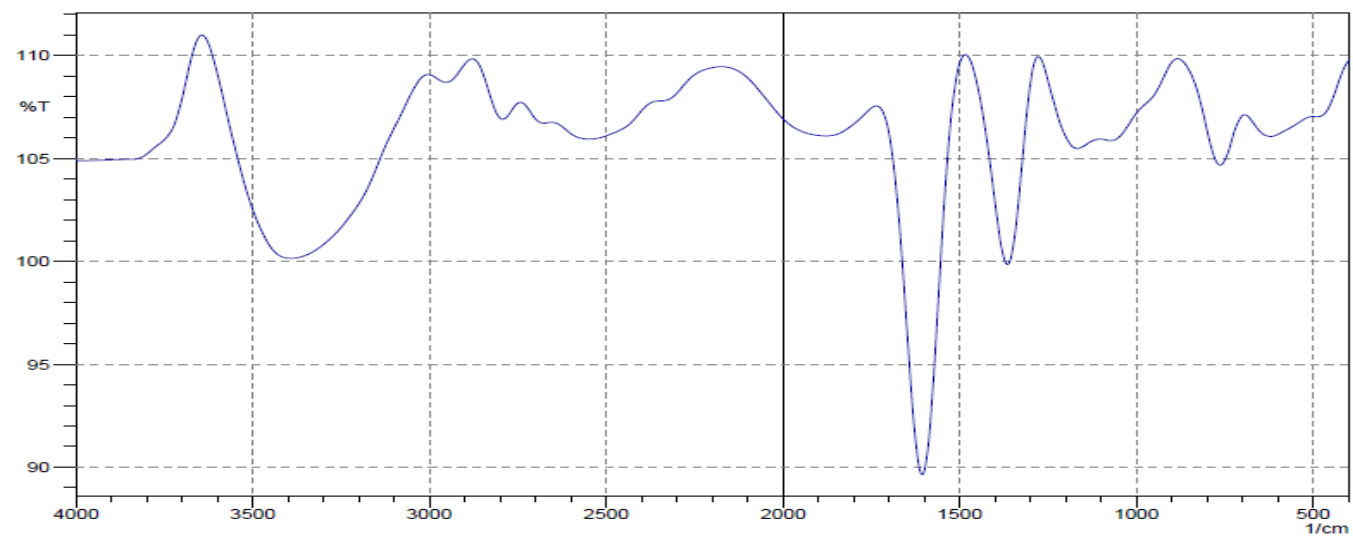

Figure 2: Identification of Lornoxicam by IR Spectrum 
Figure 2 shows IR spectrum of Lornoxicam. All major peaks of Lornoxicam drug was observed at wave numbers 3417 (2 aromatic $\mathrm{N}-\mathrm{H}$ stretching vibrations) 1637 (Aromatic $\mathrm{C}=\mathrm{O}$ stretching vibrations), 1082 ( $\mathrm{S}=$
O stretching), 3059 (C- $\mathrm{H}$ aromatic), 1539 (C=C aromatic), $1327(\mathrm{C}-\mathrm{N}) 621(\mathrm{C}-\mathrm{Cl})$ were observed which confirms identity purity of drug.

\section{Drug- Excipients Compatibility Studies by FT-IR}

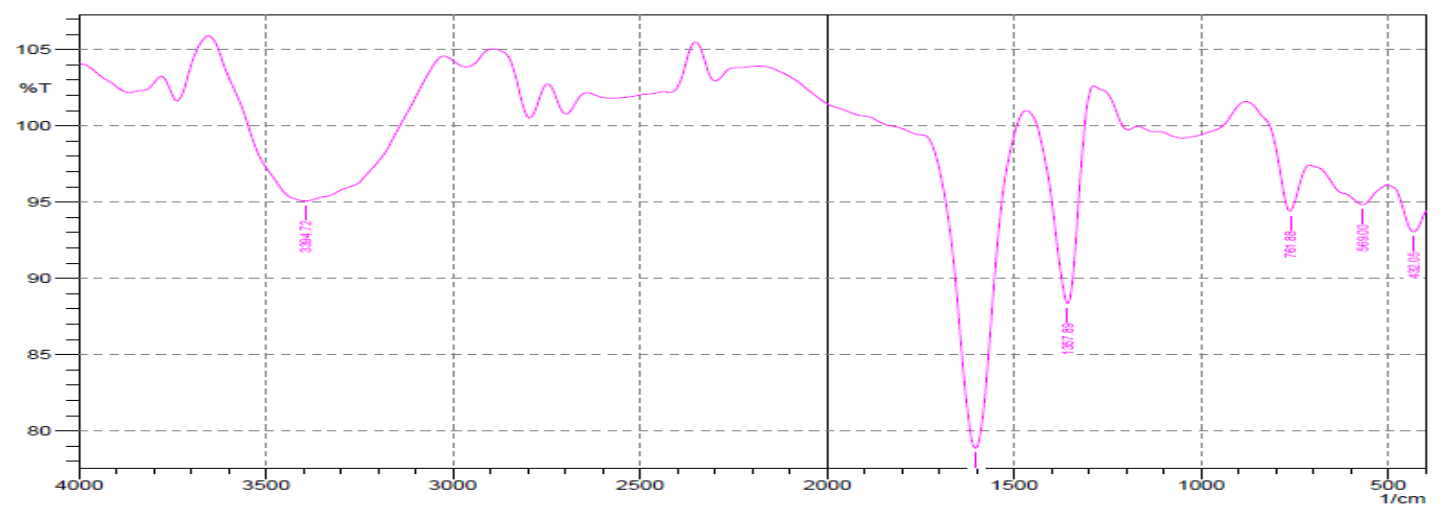

Figure 3: FT-IR Spectrum Formulation ((Lornoxicam + Eudragit RS 100 + Ethyl Cellulose + HPMC K 4 +MCC+ Cross povidone+ Aspartame+ Kyron 314)

Figure 3 show IR range of Lornoxicam medication with all excipients which utilized as part of definition having trademark assimilation band in taking after district. IR range of standard medication Lornoxicam, Ethyl cellulose, HPMC K4M, HPMC K 15, HPMC K100, Eudragit RS 100, Chitosan plan demonstrates same top, utilitarian gathering at various recurrence. Results uncovered no progressions found in IR tops of Lornoxicam, when blended with polymers. These perceptions show similarity of polymers with Lornoxicam.

FTIR Spectroscopy was utilized to study conceivable association between unadulterated Lornoxicam with different fixings in patch plan. There was no huge distinction in FTIR spectra of unadulterated medication, physical blend detailing. All significant crests of Lornoxicam was seen at wave numbers 3417 (2 sweetsmelling extending vibrations) 1637 (fragrant $\mathrm{C}=\mathrm{O}$ extending vibrations) 1082 ( $\mathrm{S}=\mathrm{O}$ extending vibrations), 1327 (C - N extending), 621 (C-Cl twisting), 3059 (C-H (aromatic) Stretching1539 ( $\mathrm{C}=\mathrm{C}$ extending) were held in physical blends Patch which unmistakably demonstrate that no cooperation exists between immaculate meditation all fixing.

Trademark tops of medication show up in spectra of blend of medication excipients same wave number, demonstrating no adjustment or communication amongst medication excipients. From that it can infer that medication has kept up its personality without losing its trademark properties.

Preliminary Selection of Type of retardant Material for Lornoxicam sustained Release layer:

Table 4: Preliminary Selection of Type of Retardant Material for Lornoxicam sustained Release layer.

\begin{tabular}{|l|l|l|}
\hline Batch & $\begin{array}{l}\text { Type of retardant } \\
\text { material }\end{array}$ & $\begin{array}{l}\text { Concentration of } \\
\text { Retardant material }\end{array}$ \\
\hline LSB1 & Ethyl Cellulose & 50 \\
\hline LSB2 & HPMC K4M & 50 \\
\hline LSB3 & HPMC K100M & 50 \\
\hline LSB4 & Eudragit & 50 \\
\hline LSB5 & Polyox WSR 303 & 50 \\
\hline
\end{tabular}

Characterization of Preliminary trial Batches (LSB1-LSB5)

EFFECT OF TYPE OF RETARDANT MATERIAL

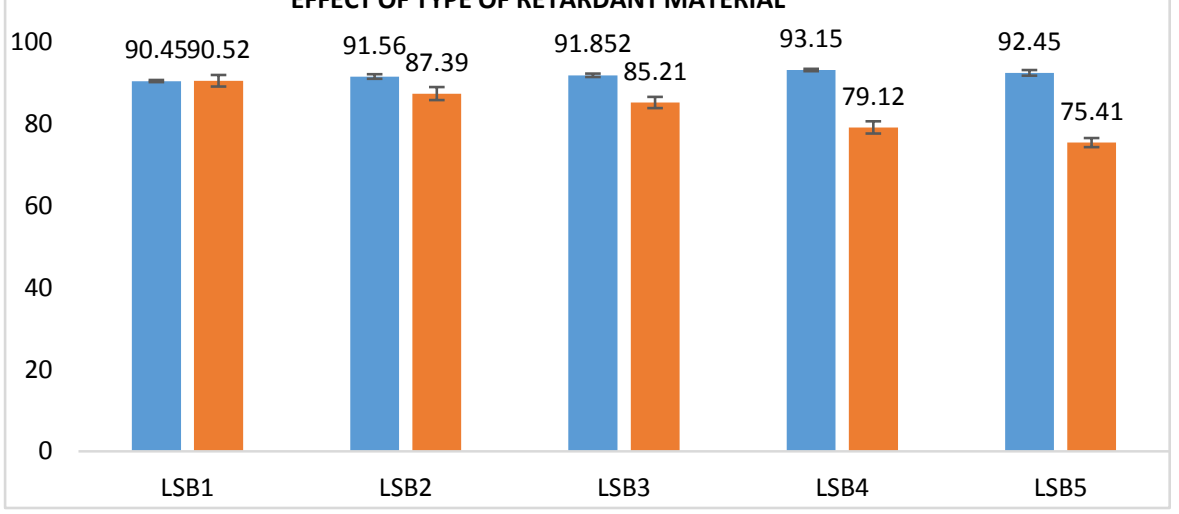

Figure 4: Effect of type of retardant material (Blue-\% Drug Content, Orange-\% CDR) 
Managed discharge drug conveyance framework required polymers which having property to supported arrival of residue when it is fused into detailing. Retardant polymer, for example, HPMC, Chitosan, Eudragit, Polyox soon are utilized as part of pharmaceutical plan to support medication discharge. Nonetheless, centralization of retardant polymer in managed discharge tablets must be ideal. Here, Polyox 303 has been observed to be extremely powerful retardant polymer for managed discharge tablet delivered by different strategies. Retardant polymer having property of swelling gelling by which they controls arrival of medication from detailing. Actually, viability of Polyox 303 in managing medication discharge is such that it even controls medication discharge without meddling with medication content. Indeed, even retardant polymer like HPMC eudragit has been used for diminishing medication discharge from tablet. Henceforth, LSB3, LSB4LSB 5 have been chosen as enhanced bunches.

\section{Preliminary Selection of Concentration of Retardant Material:}

Table 5: Preliminary Selection of Concentration of Retardant Martial on Lornoxicam sustained Release layer.

\begin{tabular}{|l|l|l|}
\hline Batch & $\begin{array}{l}\text { Type of retardant } \\
\text { material }\end{array}$ & $\begin{array}{l}\text { Concentration of } \\
\text { Retardant material }\end{array}$ \\
\hline LSB6 & HPMC K100M & 25 \\
\hline LSB7 & HPMC K100M & 50 \\
\hline LSB8 & HPMC K100M & 75 \\
\hline LSB9 & HPMC K100M & 100 \\
\hline LSB10 & Eudragit & 25 \\
\hline LSB11 & Eudragit & 50 \\
\hline LSB12 & Eudragit & 75 \\
\hline LSB13 & Eudragit & 100 \\
\hline LSB14 & Polyox WSR 303 & 25 \\
\hline LSB15 & Polyox WSR 303 & 50 \\
\hline LSB16 & Polyox WSR 303 & 75 \\
\hline LSB17 & Polyox WSR 303 & 100 \\
\hline
\end{tabular}

Characterization of Concentration of Retardant Material:

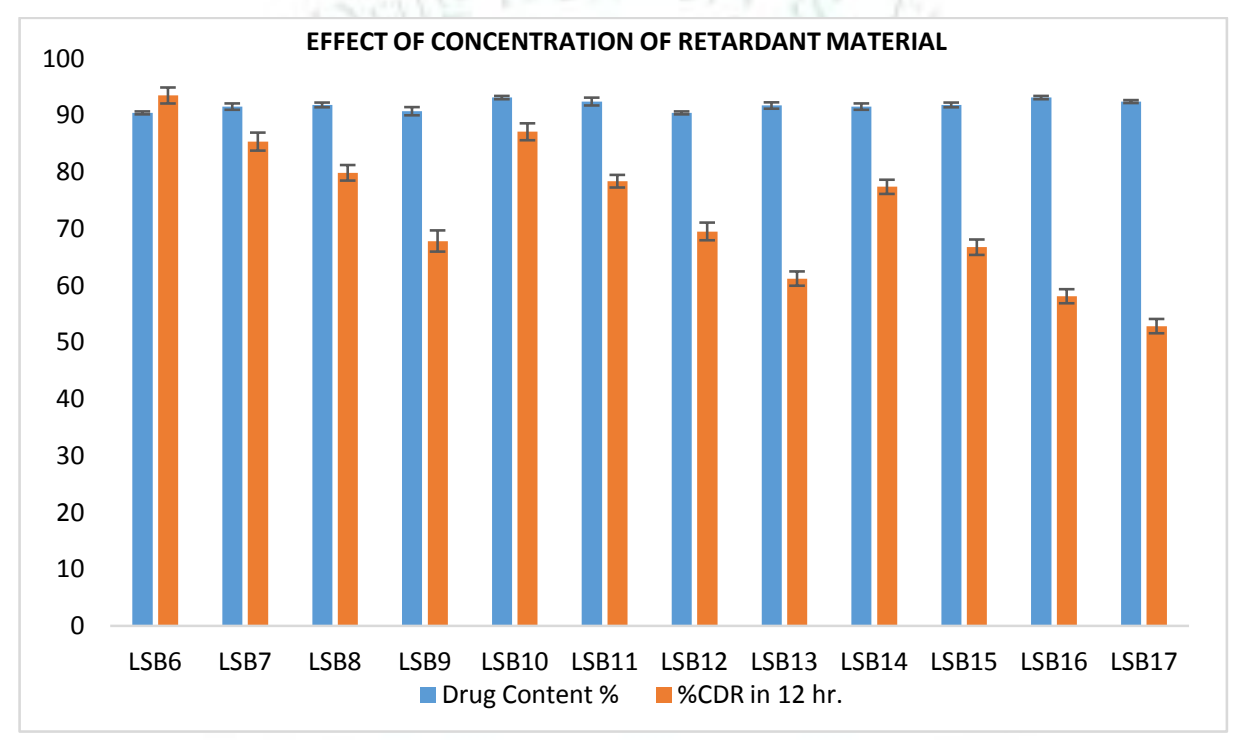

Figure 5: Effect of concentration of retardant material

As retardant material is essential prerequisite for plan of managed discharge detailing. To improve support discharge, detailing require high centralization of retardant material. According to preparatory trial groups, as convergence of retardant material increment, supporting arrival of medication increment. In this way, $100 \mathrm{mg}$ of retardant material chose as most extreme focus for detailing of managed discharge layer.

Preliminary Trial Batches for Orodispersible Layer:

Preliminary Selection of Type of Super Disintegrants:

Table 6: Preliminary Selection of Type of Super Disintegrants on Lornoxicam Orodispersible layer

\begin{tabular}{|c|c|c|}
\hline Batch & Type of Super Disintegrants & Concentration of Super Disintegrants \\
\hline LOB1 & Sodium Starch Glycolate & 10 \\
\hline LOB2 & Cross Povidone & 10 \\
\hline LOB3 & Cross Carmalose Sodium & 10 \\
\hline LOB4 & Kyron 314 & 10 \\
\hline
\end{tabular}




\section{Characterization of Trial batches (LOB1- LOB4)}

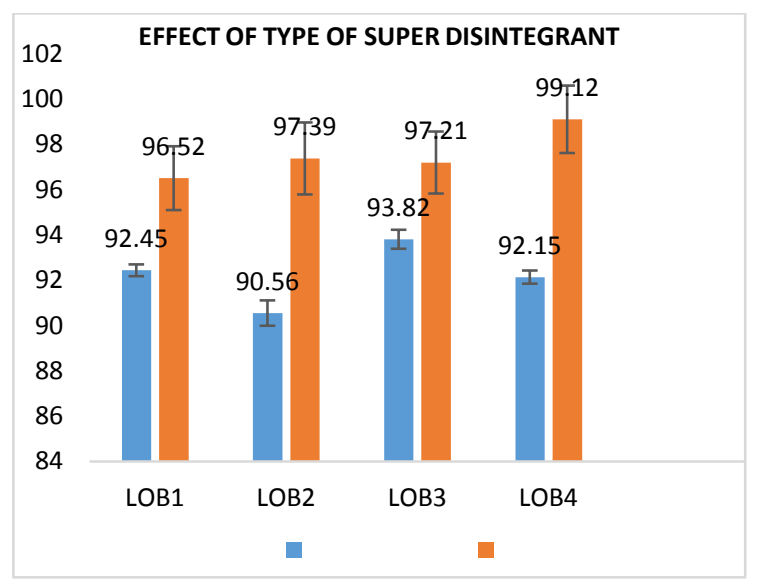

Figure 61: Effect of type of superdisintegrant (Blue-\% Drug Content, Orange-\% CDR)

Orodispersible medication conveyance framework required super disintegrant which is having property to fast arrival of medication when it is joined intoplan. Super disintegrants, for example, Sodium starch glycolate, cross povidone, cross Carmalose sodium, Kyron 314 are utilized as part of pharmaceutical definition for prompt medication discharge. Be that as it may, grouping of super disintegrants in prompt discharge tablets must be ideal. Here, Kyron 314 has been observed to be extremely powerful super disintegrants for immediate discharge tablet delivered by different techniques. Super disintegrants having property of pore framing higher water absorptivity by which they expand arrival of medication from detailing. Indeed, even super disintegrants like cross povidone, cross Carmalose sodium have been used for upgrade medication discharge from tablet. Consequently, LOB2, LOB3LOB5 have been chosen as advanced groups.

\section{In-vitro disintegration Study}

In-vitro disintegration study is important to identify disintegration time. As fast tablet disintegrate, gives faster release.

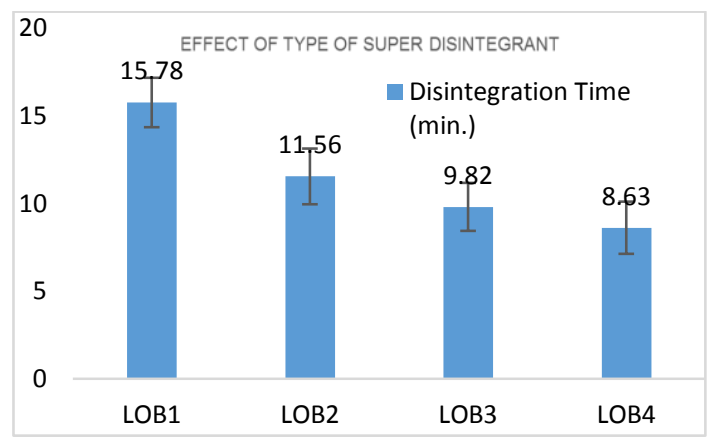

Figure 7: In-vitro disintegration study

Preliminary Selection of Concentration of Super Disintegrants:

As super disintegrants is main need for preparation of sustained release dosage form. To increase quick release, preparation requires optimum amount of super disintegration. Acoording to primary trial batches, as concentration of super disintegrants enhance, release of drug increase. So, 10 percent of super disintegrants selected as optimum concentration for formulation of Orodispersible layer.

Table 7: Preliminary Selection of Concentration of Super Disintegrants on Lornoxicam Orodispersible layer

\begin{tabular}{|c|c|c|}
\hline Batch & $\begin{array}{c}\text { Type of Super } \\
\text { Disintegrants }\end{array}$ & $\begin{array}{c}\text { Concentration of } \\
\text { Super Disintegrants } \\
(\%)\end{array}$ \\
\hline LOB5 & Cross Povidone & 2 \\
\hline LOB6 & Cross Povidone & 5 \\
\hline LOB7 & Cross Povidone & 7 \\
\hline LOB8 & Cross Povidone & 10 \\
\hline LOB9 & Cross Carmalose Sod & 2 \\
\hline LOB10 & Cross Carmalose Sod & 5 \\
\hline LOB11 & Cross Carmalose Sod & 7 \\
\hline LOB12 & Cross Carmalose Sod & 10 \\
\hline LOB13 & Kyron 314 & 2 \\
\hline LOB14 & Kyron 314 & 5 \\
\hline LOB15 & Kyron 314 & 7 \\
\hline LOB16 & Kyron 314 & 10 \\
\hline
\end{tabular}

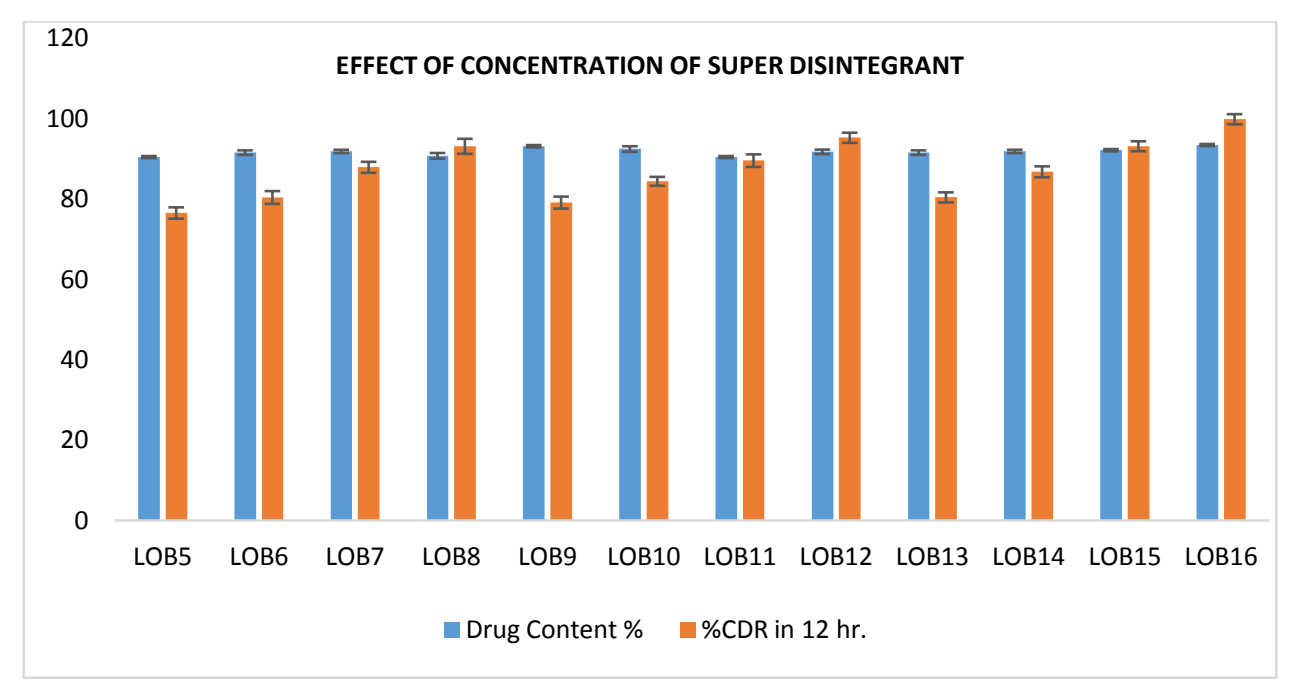

Figure 8: Effect of concentration of retardant material 


\section{In-vitro disintegration Study}

In vitro disintegration effect is significant to know disintegration time. As fast tablet disintegrate, gives faster release.

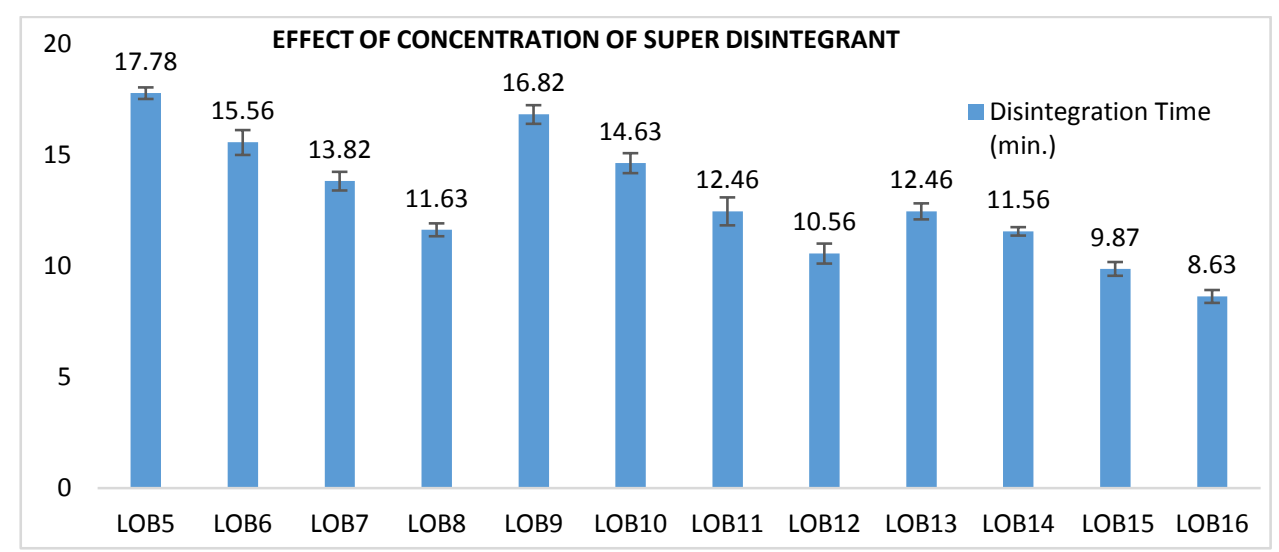

Figure 9: In-vitro disintegration study

\section{CONCLUSION}

Present investigation was finished to develop bilayer tablet of LORNOXICAM using superdisintegrant Kyron 314 for snappy release layer Polyox 303 for supporting release layer. Tablets exhibited fundamental burst release to give stacking estimation of pharmaceutical took after by kept up release up to $24 \mathrm{hrs}$. This balanced release bilayer tablets moreover diminished dosing repeat, manufacture bioavailability give better patient consistence.

\section{REFERENCES}

1. Jha MK, Rahman MH and Rahman MM, "Biphasic oral solid drug delivery system: a review." Int. J. Pharm Sci and Res, 2, 2011, 1108- 1115.

2. Saravanan V., Revathi R., Meera N. Method development and validation for the simultaneous estimation of lycopene and ubidecarenone by RP-HPLC in combined pharmaceutical dosage form. Journal of Drug Delivery and Therapeutics, 2016; 6(5): 46-51.

3. Abebe A, Akseli I, Sprockel O, Kottala N, and Cuitino AM, "Review of Bilayer Tablet Technology." International. J. Pharmaceutics, 461, 2014, 549- 558.

4. Dagariya RK, Jat RK, Method development and validation of Irbesartan chlorthalidone and Cilnidipine in their combined tablet dosage form by high performance liquid chromatography, Journal of Drug Delivery and Therapeutics. 2017; 7(4):88-96 DOI: http://dx.doi.org/10.22270/jddt.v7i4.1471

5. Kumar AP, Pramodaganta, Bhoopathi SG and, Kulkarni SV, "Current Innovation in Layered Tablet Technology: Review." Asian. J. Res pharm. sci. 3, 2013 189-194.

6. Garg A, Gupta MM, Taste masking and formulation development \& evaluation of mouth dissolving tablets of levocetrizine dihydrochloride, Journal of Drug Delivery \& Therapeutics; 2013; 3(3):123-130
Bi-layer tablet is upgraded valuable development to vanquish obstruction of single layered tablet. It is proper for progressive entry of medicines for bolstered release tablet in which one layer is snappy release as starting dose second layer is upkeep estimations. Course of action of tablets as multi layers is used to offer structures to association of meds, which are opposite to give controlled release tablet game plans by giving incorporating or various swelling layers.
7. Cutolo M, Straub RH, Buttgereit F. Circadian rhythms of nocturnal hormones in rheumatoid arthritis: translation from bench to bedside. Ann Rheum Dis 2008; 67 (7):905-908.

8. Patil S, Gupta V. Design and in vitro evaluation of multiparticulate system for the chronomodulated delivery of lornoxicam. Journal of Drug Delivery and Therapeutics, 2015; 5(3):62-71. doi:10.22270/jddt.v5i3.1148

9. Merck \& Co. Inc. The Merck index. 13th ed. Whitehouse Station: Merck \& Co. Inc.; 2001.

10. Momin S, Khan S, Ghadage DM, Yadav AV, Wagh A, Formulation and evaluation of bilayer tablets of propranolol hydrochloride, Journal of Drug Delivery and Therapeutics. 2017; 7(2)50-57. DOI: http://dx.doi.org/10.22270/jddt.v7i2.1399

11. Debajyoti Ray, Amresh K Prusty. Designing and invitro studies of gastric floating Tabletss of Tramadol hydrochloride, Int J Appl Pharm. 2010; 2(4):12-16.

12. Patel K, Vyas J, Upadhyay U. Formulation and evaluation of sustained release matrix tablets of nateglinide. Journal of Drug Delivery and Therapeutics, 2015; 5(5):19-25. Doi:10.22270/jddt.v5i5.1130

13. Agrawal R, Pharmaceutical processing- a review on wet granulation technology. IJPFR. 2011; (1):65-83 